\title{
Konzultace
}

\section{HISTORIE KONCEPTU PŘIROZENÉHO MONOPOLU}

Martin Hon, Katedra ekonomie, Ekonomická fakulta, VŠB-TU Ostrava

\section{Úvod}

V této práci se zabývám historií konceptu přirozeného monopolu. Cílem je zdokumentovat změny v chápání tohoto pojmu. Jsem přesvědčen, že tento historický exkurz poskytuje mnoho podnětných myšlenek, bez ohledu na to, že řada z nich již byla vývojem ekonomik překonána či popřena.

Přirozený monopol stojí u většiny ekonomů tak trochu na okraji zájmu. Jako by byli přesvědčeni, že se jedná o zcela okrajový jev bez zásadnějšího vlivu na společnost, který lze jednoduše a stručně shrnout do poučky o klesajícím průběhu průměrných nákladi̊. Výjimku z tohoto pravidla představuje například Američan Richard T. Ely, který byl přesvědčen, že industrializace ekonomik nutně povede k postupnému zmonopolizování většiny odvětví právě z důvodu vzniku přirozeně monopolních podmínek.

Níže uvedený přehled nelze v žádném případě považovat za zcela vyčerpávající. Měl by však obsahovat nejdůležitější momenty, které ovlivnily názory ekonomů i širší odborné veřejnosti. Způsob chápání přrirozeného monopolu sehrává velmi důležitou roli, nebo se od něj přímo odvozuje to, jak stát reguluje (či nereguluje) daná odvětví, která velmi často označujeme jako strategická, životně důležitá apod.

\section{Historie konceptu přirozeného monopolu}

Pojem monopol byl poprvé použit již Aristotelem. Ale kdy vznikl pojem přirozený monopol? Adam Smith tento termín nikdy nevyslovil, přesto byl prvním, kdo detailně ve svém díle Pojednání o podstatě a původu bohatství národů (kniha I, kapitola VII, str. 56) charakterizoval takovou situaci, která byla posléze označena jako přirozený monopol.

„Některé plodiny vyžadují tak zvláštní půdu a polohu, že veškerá půda celé velké země, na níž se mohou pěstovat, nestačí třeba krýt účinnou poptávku. Celé množství dodané na trh se rozprodá tedy třeba těm, kteř́i jsou ochotni dát více, než kolik by stačilo uhradit rentu z půdy, na níž byly ony plodiny vypěstovány, mzdu za práci i zisk z kapitálu, jichž bylo použito při jejich pěstování a dopravě na trh, podle prrirozené míry těchto složek. Takové zboží se může prodávat za tuto vysokou cenu po celá staletí a ta její část, jež představuje rentu $\mathrm{z}$ půdy, je v tomto případě obyčejně vyšší než míra přirozená. ... 
Takové zvýšení tržní ceny bývá zřejmě následkem přirozených příčin, jež nikdy nedovolí, aby účinná poptávka byla plně uspokojena, a jež tedy mohou působit trvale.“

Za autora pojmu přirozený monopol je považován Robert Malthus, který v roce 1815 vydal esej The Nature of Rent.

„V souvislosti s rentou existují okolnosti, které mají blízký vztah k přirozenému monopolu. ... Určité vinice ve Francii díky zvláštnosti půdy a prostředí poskytují exklusivní vína specifických chutí, která jsou samozřejmě prodávána za cenu na hony vzdálenou od výrobních nákladů.“

Původně byl tedy pojem přirozený monopol vztažen k situaci, kdy především př́írodní podmínky zabraňovaly vzniku tržní konkurence a odpovídal stavu, kdy daná firma vlastní jedinečný výrobní faktor.

Přestože byl pojem přirozený monopol použit, stále chyběla jeho přesná definice. Tu nalezneme až u Johna Stuarta Milla, který přirozený monopol chápe jako „takový, který vznikly díky okolnostem a nikoliv ze zákona“. (The Principles of Political Economy, 1848) V knize první, kapitole deváté, nalezneme následující úvahu:

„Např́klad je zřejmé, jak mnoho práce by se ušetřilo, kdyby Londýn byl zásobován pouze jedinou plynárenskou či vodovodní společností namísto existujícího množství. I když budou pouze dvě firmy, znamená to zdvojení všeho, zatímco když bude jenom jedna, tak bude pravděpodobně zvládat všechny činnosti stejně dobře s pouze malým zvýšením nákladů.“

Tento př́klad již odpovídá současnému pojetí přirozeného monopolu, jehož podstata spočívá ve specifickém průběhu produkčních a nákladových funkcí vzhledem k velikosti daného trhu. To však neznamená, že by Mill (a jeho současníci) nechápali pod tímto pojmem i monopol, který existuje díky vlastnictví specifického výrobního faktoru. Za přirozený monopol byl chápán jakýkoliv monopol, který nevznikl ze zákona, tj. záměrným rozhodnutím vlády.

Ve stejné době nastává velký pokrok v ekonomickém myšlení díky práci francouzských myslitelů. Konkrétně Augustin Cournot byl první, kdo v roce 1838 definoval monopol jako prodávajícího, který čelí klesající poptávkové křivce. Odvodil, že monopolista je schopen si sám zvolit cenu místo toho, aby akceptoval převládající cenové relace. Cournotův př́ílad byl velmi názorný - majitel pozemku, na němž pramenila minerální voda, zjistil, že je schopen prodávat tuto vodu, ale uvědomoval si, že zvyšovat prodávané množství lze pouze tehdy, pokud snižuje požadovanou cenu. Cournot definoval optimální cenovou strategii pro prodávajícího, která vedla k známému pravidlu maximalizace zisku - mezní př́ijem se rovná mezním nákladům.

Jules Dupuit, francouzský inspektor železnic, přispěl k teorii monopolu v roce 1849 dalším významným poznatkem. Zatímco hledal způsob jak změřit př́nos veřejných pracích pod jeho jurisdikcí ke společenskému blahobytu, objevil, že ten, kdo je schopen cenové diskriminace - účtovat různé ceny různým spotřebitelům - je veden k volbě takového výstupu, který maximalizuje společenský blahobyt (respektive na základě cenové diskriminace je možné vybrat potřebnou částku na pokrytí nákladů s menší ztrátou celkové užitečnosti). Tento poznatek vede k závěru, že některá odvětví ekonomiky budou lépe „obsluhována“ monopolistou maximalizující zisk než navzájem si konkurujícími firmami. 
Zejména ale na základě zkušeností ze svého povolání popisuje možný případ přirozeného monopolu - dopravní infrastrukturu (sám místo pojmu přirozený monopol používá výraz „de facto monopol“). Důvod jeho existence spatřuje zejména $\mathrm{v}$ tom, že pro novou firmu je v podstatě nemožné vstoupit na trh a to ze tř́ důvodů:

1) obrovské množství kapitálu potřebného ke vstupu na trh je dostupné pouze omezenému počtu podnikatelů;

2) nová firma by odváděla zákazníky stávajícímu monopolu a zisk by tak nebyl dostatečně velký na to, aby pokryl fixní náklady obou firem;

3) první firma na trhu využije nejlepší podmínky.

Jak Dupuit ř́ká, „místo jednoho dobrého podnikání budeme mít dvě špatné“ (Mosca, 2007).

K podobným závěrům dochází i další francouz - Léon Walras. V článku L'état et les chemins de fer (1875) uvádí i on jako př́klad přirozeného monopolu železnici a existencí přirozeného monopolu spolu se společenským významem železnice obhajuje potřebu státní intervence.

Je zřejmé, že francouzští i angličtí ekonomové si čím dál více uvědomovali, že možnou prŕččnou vzniku monopolu je to, co dnes označujeme jako tzv. úspory z rozsahu. Ekonom Nassau W. Senior ve svém díle Political Economy (1850) $\mathrm{v}$ kapitole čtvrté člení monopoly do čtyř skupin z hlediska přičin jejich vzniku. Hned na prvním místě popisuje monopol jako situaci,

„kde monopolista nemá výlučnou moc k výrobě, ale jako výrobce má pouze určité výjimečné technické prostředky a může zvýšit objem své produkce bez snížení či zvýšení objemu výrobních prostředků. ...

jak se zvyšuje objem produkce, relativní náklady produkce se zmenšují“.

Nejpropracovanější a v jistém slova smyslu i nejtechničtější analýzu úspor z rozsahu nalezneme u Alfreda Marshalla. Ve svém stěžejním díle Principles of Economics (1890) v knize čtvrté, kapitole deváté, rozlišuje tzv. vnější (external) a vnitřní (internal) úspory z rozsahu:

„Úspory pramenící z rostoucího rozsahu výroby jakéhokoliv druhu zboží můžeme rozdělit do dvou kategorií - zaprvé jsou to ty, které závisí na obecném vývoji odvětví a zadruhé se jedná o ty, které závisí na zdrojích využívaných jednotlivými firmami, na jejich organizaci a na efektivnosti jejich řízení.“

Dle Marshalla byl Cournotův př́klad s minerální vodou jasnou ukázkou alokační neefektivnosti monopolu. Protože voda vyvěrá ze země „zadarmo“ a její zdroj je považován za nevyčerpatelný, je společensky optimální cena rovna nule. Ale monopolní cena je vyšší a tudíž způsobuje nižší uspokojení spotřebitelů. Marshall rovněž poukázal na to, že pravděpodobnost vzniku monopolu závisí na nákladových podmínkách a produkčních funkcích v daném odvětví. Odvětví s rostoucími průměrnými náklady budou pravděpodobně konkurenční, zatímco odvětví s klesajícími průměrnými náklady budou mít tendenci $\mathrm{k}$ monopolizaci. Marshall si uvědomoval, že v odvětví s klesajícími náklady mohou být monopoly společensky účelné, 
nebo jejich cena může být nižší a výstup vyšší, než by odpovídalo konkurenčnímu odvětví.

Sám však připouští, že není schopen přesně určit podmínky dlouhodobé rovnováhy odvětví za předpokladu rostoucích výnosů z rozsahu. V dodatku $\mathrm{H}$ Principles of Economics analyzuje tendence, které budou v takovémto odvětví působit a dospívá $\mathrm{k}$ tomu, že existuje více rovnovážných bodů. Graficky tuto možnost prezentuje v poznámce pod čarou následujícím grafem:

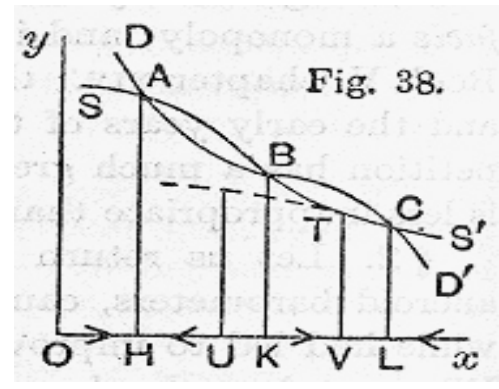

Z něho vyplývá, že dané odvětví se může nacházet ve stabilní rovnováze (body A a C) či v nestabilní rovnováze (bod $B$, kterou Marshall přirovnává $\mathrm{k}$ vejci stojícímu na špičce).

Přesuňme nyní pozornost do Spojených států amerických. Ekonom Richard T. Ely jakožto stoupenec německé historické školy a předchůdce institucionalismu, se nespokojil s obecným konstatováním, že v pozadí přirozeného monopolu stojí úspory $\mathrm{z}$ rozsahu, ale důsledně analyzoval jednotlivá odvětví.

Ely rozlišuje tři kategorie přirozeného monopolu. První typ je závislý na jedinečném zdroji nabídky (např́iklad Cournotův zdroj minerální vody); druhý je založen na jedinečných znalostech (patenty); třetí typ pramení z „finančních potřeb“ daného odvětví. Přirozený monopol tak odpovídá třetí kategorii a dle Elyho plyne ze tří skutečností, které samy o sobě ničí hospodářskou soutěž. K vytvoření monopolu je však nezbytné jejich společné působení. Jsou to:

1) nabízené zboží či poskytovaná služba musí být takového druhu, že i malá změna $\mathrm{v}$ ceně vede spotřebitele $\mathrm{k}$ přechodu od jednoho výrobce ke druhému;

2) odvětví musí mít takový charakter, že je nemožné vytvořit dostatečné množství konkurujících si podniků. Důvodem mohou být jak úspory z rozsahu, tak i jakékoliv jiné překážky (převážně technického charakteru), které stanoví konečný počet producentů v daném odvětví;

3) podíl fixních nákladů $\mathrm{k}$ variabilním nákladům musí být vysoký.“

Přirozený monopol je brán jako situace, kdy konkurence je pro dané odvětví „nevhodná“. Tato ,nevhodnost“ může pramenit jednak z úspor z rozsahu, ale, jak Ely zdůrazňuje, i z jiných př́čin, které způsobí, že samotné konkurenční síly vedou k eliminaci hospodářské soutěže. 
V článku Natural Monopolies and the Workingman (1894) Ely uvádí následující prríklady přirozeně monopolních odvětví - železnice, telegrafy, telefony, kanalizace, zavlažování, přístavy, plynárny, elektrické dráhy apod.

Sám měl z existence přirozených monopolů značné obavy, a proto doporučoval jejich př́isnou státní kontrolu. V uvedeném článku upozorňuje na to, že přirozeně monopolní firma (respektive její majitelé) dosahují abnormálních zisků a dochází tak k nespravedlivému přerozdělování bohatství ve společnosti. Rovněž považuje za závažné, že roste závislost celé společnosti na přirozeně monopolních odvětvích (železnice, telekomunikace, rozvody energií atd.) a upozorňuje na rostoucí ekonomickou moc přirozeně monopolních firem.

„Tvrdí se, že samotné železnice ve Spojených státek amerických představují jednu pětinu celkového národního bohatství. Je to nepochybně nadsazený odhad, ale pravděpodobně podhodnocené je tvrzení, že tato odvětví představují jednu čtvrtinu z celého bohatství naší průmyslové civilizace. Navíc jejich podstata je taková, že každý jiný typ podnikání je na nich př́mo či nepř́mo závislý.“

Poprvé se zde objevuje nový pohled na existenci přirozeného monopolu. Monopolní firma může být lepším řešením než konkurenční firmy, a to z důvodu větší efektivnosti i z důvodu větší stability odvětví, ale je potřeba ji regulovat. Ely byl přesvědčen o tom, že nejlepši formou bude státní vlastnictví.

Přirozený monopol analyzuje i institucionalista John R. Commons např́klad ve svém článku Protection and Natural Monopolies (1892). Jeho pojetí prrirozeného monopolu má stále blízko $\mathrm{k}$ monopolu prrírodnímu $\mathrm{v}$ tom smyslu, že ekonomický subjekt získává monopolní postavení díky vlastnictví specifického zdroje či specifickému umístění jeho produkce. Commons si byl vědom toho, že v situaci volné konkurence na trhu výrobních faktorů připadne jakýkoliv př́ípadný ekonomický zisk přirozenému monopolistovi - např́klad provozovateli dopravní infrastruktury či majiteli dolu, lomu apod. Commons proto navrhoval uvalit speciální daně na spekulativní držbu dolů či lomů a především doporučoval přesunout daňové zatížení práce a kapitálu na přirozené monopoly.

Američan Thomas H. Farrer se snažil popsat přirozený monopol na základě několika ekonomických charakteristik. V knize The State in Its Relation to Trade (1902) považuje za přirozené monopoly taková odvětví, v nichž hospodářská soutěž nikdy nenastala, nebo v kterých neměla dlouhého trvání. Vyjmenoval pět základních charakteristik, přičemž se domníval, že všechny musí být splněny, abychom mohli hovořit o skutečném přirozeném monopolu v odvětví:

1) odvětví musí nabízet životně nezbytný výrobek nebo službu;

2) výrobce musí být vzhledem $\mathrm{k}$ dané produkci vhodně umístěn;

3) výstup odvětví nelze skladovat;

4) produkce musí být provázena úsporami z rozsahu;

5) zákazníci musí požadovat stoprocentní garanci na dodávku zboží s přesně stanoveným časovým harmonogramem, což může zajistit pouze jediný prodávající.

V roce 1887 američan Henry C. Adams analyzoval přirozený monopol v práci Relation of the State to Industrial Action. Odvětví rozdělil do tř́ skupin podle toho, 
zdali průměrné náklady s objemem produkce rostou, zůstávají konstantní či klesají. V prvních dvou př́padech je hospodářská soutěž možná, odvětví s klesajícími průměrnými náklady vyžaduje státní regulaci.

„Tam, kde existují rostoucí výnosy, ztrácí volná soutěž svou schopnost samovolné regulace trhu. Důvodem je fakt, že pro zavedenou firmu je daleko snazší rozššririt své výrobní kapacity k uspokojení rostoucí poptávky, než pro novou firmu vstoupit do odvětví... Na takovéto odvětví by měl dohlížet stát... Takovéto odvětví je přirozeným monopolem..." (Sharkey, 1989)

Adams zjednodušil definování monopolu na čistě technickou podmínku úspor z rozsahu v odvětví. Byl jedním z prvních, kdo navrhoval přímou regulaci přirozených monopolů jako cestu $\mathrm{k}$ maximalizaci společenského blahobytu. Regulaci chápal jako nástroj, který umožní jediné firmě získat veškeré výhody z velkého rozsahu produkce, ale který bude chránit spotřebitele před zneužitím monopolní síly.

Postupem doby byl koncept přirozeného monopolu spojován výhradně s existencí úspor z rozsahu a z nich vyplývajícími klesajícími průměrnými náklady. Jednalo se tedy o ta odvětví, která byla charakterizována vysokými fixními náklady a velice nízkými (až nulovými) variabilními (respektive mezními) náklady.

V 60. letech 20. století se však pomalu začínají objevovat názory, že klesající průměrné náklady nejsou nutnou podmínkou pro existenci přirozeného monopolu. Např́klad James C. Bonbright ve své knize Principles of Public Utility Rates (1961) ř́ká:

„Tato podmínka (klesající průměrné náklady, respektive úspory z rozsahu) je zcela neopodstatněná. Ignoruje skutečnost, že i když jednotkové náklady na poskytování dané veřejné služby musí vzrůst s rostoucí mírou produkce, jakákoliv úroveň výstupu bude nejekonomičtěji dodávána jedinou firmou či jediným systémem.“

Jako př́íklad je uváděna výroba elektřiny, kdy stávající poptávka je pokrývána levnou výrobou vodních elektráren a dodatečná poptávka musí být uspokojena zapojením dražší tepelné elektrárny.

Ještě dále jde Harold Demsetz, který ve svém článku Why Regulate Utilities? (1968) tvrdí:

„Teorie přirozeného monopolu je neúplná (vadná), nebo v ní chybí logické kroky, které propojí úspory z rozsahu při výrobě s monopolní cenou na trhu. ...

Existence úspor z rozsahu je irelevantní při determinování počtu konkurujících si nabízejících. ... Teorie přirozeného monopolu je jasně nejasná.“

Př́kladem ze současnosti může být existence tř́ operátorů mobilních telefonů v České republice. Toto odvětví je s velkou mírou pravděpodobnosti v tradičním pojetí přirozeně monopolní. Působí zde úspory z rozsahu, podíl fixních nákladů na celkových nákladech je vysoký, mezní náklady na posledního zákazníka jsou téměř nulové (minimálně z hlediska investice do technologie; marketingové náklady jsou zřejmě větší), v jistém slova smyslu zde dochází k plýtvání se zdroji atd. Přesto se zákazníci dobrovolně rozhodli financovat více než jednu firmu.

Přelom 70. a 80. let 20. století lze charakterizovat snahou najít matematicky přesnou definici přirozeného monopolu pro situaci, kdy firma vyrábí současně více produktů. Hlavního pokroku v této oblasti dosáhli John C. Panzar a Robert D. Willig, kteří spolu publikovali sérii článků - Economies of Scale in Multi-Output Production (1977), Free 
Entry and the Sustainability of Natural Monopoly (1977) a Economies of Scope (1981) a dále William J. Baumol, který ve svém článku On the Proper Cost Tests for Natural Monopoly in a Multiproduct Industry (1977) ř́ká:

„Literatura je obecně poněkud vágní ohledně okolností, za kterých monopol poskytuje nákladovou výhodu ve srovnání s výrobou ve velkém počtu firem. ...

... úspory z rozsahu nejsou ani nutnou ani dostačující podmínkou pro to, aby monopol byl nejméně nákladnou formou produkce. Přesněji řečeno, klíčovým konceptem je striktní subaditivita nákladové funkce, což znamená, že suma nákladů na $m$ vektorů výstupu je menší než suma nákladů při oddělené produkci.“

Definice přirozeného monopolu na základě subaditivity nákladových funkcí je naprosto exaktní, z praktického hlediska je však její přínos téměř nulový. Nikdy totiž nebudeme mít $\mathrm{k}$ dispozici všechny potřebné informace $\mathrm{k}$ tomu, abychom byli ex-ante schopni říci, zdali dané odvětví má přirozeně-monopolní charakter.

Ve stejné době získává popularitu teorie tzv. vybojovatelných trhů (contestable markets). Její podstata spočívá v následující myšlence - pokud existuje zcela volný vstup do odvětví a výstup z odvětví nepřináší žádné náklady, je na monopolní firmu vytvářen tlak ze strany potenciálních konkurentů. A monopolní firma se díky tomu začne chovat takovým způsobem, jakoby působila na konkurenčním trhu. Srozumitelně je tato idea podána Williamem J. Baumolem ve stati Contestable Markets: An Uprising in the Theory of Industry Structure (1982).

Tento nový pohled na chování monopolů a oligopolů ovlivnil především přístup regulačních orgánů. Nezáleží na počtu firem, ale na obecných podmínkách pro podnikání. Přirozený monopol, respektive jeho chování, není předurčeno „tvarem“ nákladových křivek, ale rozsahem potenciální konkurence. Nejúčinnější regulace tedy spočívá v odstraňování překážek vstupu do odvětví.

$\mathrm{V}$ tomto historickém přehledu nelze opomenout myšlenky tzv. rakouské školy. Jejich pohled na přirozený monopol vystihují slova Thomase J. DiLorenza z článku The Myth of Natural Monopoly (1996):

„Teorie přirozeného monopolu je ekonomická fikce. Nic takového jako „přirozený“ monopol nikdy neexistovalo. Historie konceptu tzv. veřejných služeb (public utility) je taková, že na přelomu devatenáctého a dvacátého století poskytovatelé veřejných služeb tvrdě soutěžili a stejně jako v jiných odvětvích neměli soutěž rádi. Nejprve si zajistili vládou garantované monopoly a poté s pomocí pár vlivných ekonomů vytvořili ex post odůvodnění pro jejich monopolní sílu.“

Při formulování takto ostře vyhraněných myšlenek vychází rakouská škola z pojetí trhu jako procesu objevování a učení se.

V posledních patnácti letech je debata o přirozených monopolech zúžena na př́ípady tzv. sí ových odvětví - energetika, telekomunikace, vodovody a kanalizace apod. Při hledání efektivní formy regulace se pozornost soustředí nikoliv na přirozeně monopolní firmu či odvětví, ale na přirozeně monopolní činnost.

Podle této myšlenky je chybou považovat např́iklad elektroenergetiku jako celek za přirozený monopol, nebo prrirozeně monopolní je pouze přenos a distribuce. Konkurence je možná i společensky prospěšná. Stačí zajistit rovný přístup soutěžitelů (v našem případě výrobců a prodejců elektrické energie) k přenosové soustavě. A to lze 
jedině jejím vyčleněním z vertikálně integrované firmy do samostatné jednotky tak, aby na její chod neměl vliv žádný z existujících ani potenciálních konkurentů.

Jsem přesvědčen o tom, že tento př́stup, který dnes tak silně ovlivňuje postoje regulačních orgánů, je špatný a plyne z nepochopení podstaty firmy a přirozeného monopolu. Proč existuje firma? Pro moji analýzu využiji odpověd', kterou roku 1937 poskytl Ronald H. Coase v článku The Nature of the Firm. Př́ŕčnou vzniku firmy jsou transakční náklady, které rozhodnou o tom, kterou činnost si firmy bude zajiš ovat interně a které již bude uspokojovat skrze tržní mechanismus. Firma poroste do bodu, ve kterém náklady na provádění aktivity uvnitř firmy se rovnají nákladům na provádění aktivity prostřednictvím tržní transakce.

Při tomto pojetí firmy je zřejmé, že nařízené ,,vytržení“ části produkčního procesu z firmy povede $\mathrm{k}$ nárůstu transakčních nákladů, které nakonec vždy zaplatí zákazník. Situace je o to horší, že rozhodovací mechanismus uvnitř firmy nebude nahrazen tržním mechanismem, ale administrativním rozhodnutím regulátora.

Vra me se k mému př́kladu z elektroenergetiky. Rozbití přirozeně monopolní firmy vyvolalo otázku, jak zabezpečit obnovu a rozvoj přirozeně monopolní infrastruktury. Firma je v přirozeně monopolním postavení právě díky vlastnictví přirozeně monopolní infrastruktury. $Z$ této teze vyplývá, že takováto firma má bytostní zájem na udržování a rozšiřování této infrastruktury. $\mathrm{V}$ momentě, kdy však přístup $\mathrm{k}$ sítím získají všechny firmy, žádná z nich nebude motivována do nich investovat.

$\mathrm{S}$ transakčními náklady souvisí i koordinační problém. V případě přirozeně monopolní energetické firmy je rozhodování o výrobních kapacitách (a již jejich obnova, budování nových či jejich útlum) neoddělitelně koordinováno s rozvojem přenosové infrastruktury. Kdo však tuto koordinaci zajistí při vyčlenění přenosové soustavy do nezávislé jednotky? A je vůbec možná?

Podle mého názoru nikoliv a to z několika důvodů. Zaprvé „správce“ přenosové soustavy potřebuje pro plánování rozvoje sítě informace o dlouhodobých záměrech výrobců elektrické energie. Těžko lze však očekávat, že konkurující si výrobci budou ochotni poskytovat nezkreslené informace o svých plánech. Zadruhé je zde problém s nalezením „spravedlivého“ způsobu financování. Vzhledem k fyzikálním vlastnostem elektrické energie je nemožné přesně stanovit, kdo a jakým podílem využívá danou část soustavy. Zatřetí stojí správce infrastruktury před otázkou volby odpovídající technologie (tento problém je zvláště patrný v př́padě telekomunikační infrastruktury).

Samostatnou otázkou je i nezbytnost koordinace samotných výrobních kapacit. V dané energetické soustavě je potřeba zajistit určitý technologický mix tak, aby bylo zajištěno pokrytí jakékoliv odběrové špičky (jinak by došlo k selhání celého systému) při zachování rozumných nákladů pro zákazníka.

Pokud koordinace probíhá $\mathrm{v}$ rámci jediné přirozeně monopolní firmy, může regulátor ,pouze“ stanovit konečné cíle firmy a zajistit kontrolu jejich plnění. Rozbití přirozeného monopolu na druhou stranu vyvolá transakční náklady a postaví regulátora před neřešitelný problém zajištění koordinace činnosti mezi mnoha nezávislými ekonomickými subjekty. Předpokládám tedy, že je jen otázkou času, kdy zainteresované strany opustí nynější koncept přirozeně monopolní činnosti a vrátí se $\mathrm{k}$ přirozeně monopolní firmě, respektive odvětví. 


\section{Závěr}

Pojem přirozený monopol bude zanedlouho slavit již 200 let. Za tuto dobu se mnoho ekonomů snažilo porozumět př́činám jeho vzniku a rovněž tak důsledkům, které jeho existence přinese společnosti.

Téměř všichni dospěli k tomu, že přirozený monopol je zcela specifický fenomén, nebo $v$ sobě obsahuje dvě protichůdné tendence. Na jedné straně jeho existence zvyšuje společenský blahobyt díky snižování výrobních nákladů, na straně druhé však tak jako každý monopol může snižovat společenský blahobyt $\mathrm{v}$ důsledku existence nákladů mrtvé váhy, respektive zneužití monopolní síly.

Z výše uvedeného vyplývá takřka všeobecné přesvědčení o potřebě státního dozoru či regulace. Zde již však vznikají problémy. Optimální, efektivní regulace muže být zavedena jen tehdy, pokud budou správně identifikovány prríčiny vzniku přirozeného monopolu. Jak však plyne $\mathrm{z}$ výše uvedeného přehledu, shoda $\mathrm{v}$ této otázce rozhodně nepanuje.

Stačí přirozeně monopolní odvětví definovat pouze na základě klesajícího průběhu křivky průměrných nákladů? Či je snad podstata přirozeného monopolu ukryta v subaditivitě nákladových funkcí? Nebo je potřeba každý př́ípad analyzovat individuálně podle mnoha kritérií?

Otázka správného pojetí přrirozeného monopolu je stále otevřená. Podle mého názoru je nutné vrátit se do historie a připomenout si J. S. Milla - přirozený monopol je takový, který vznikl díky okolnostem a nikoliv ze zákona.

$Z$ této prosté definice vyplývá několik důležitých poznatků. Zaprvé je nemožné předem „odhadnout“, které odvětví bude či nebude přirozeně monopolní. Zadruhé nelze zredukovat pojem přirozený monopol na určitou matematickou vlastnost nákladových či produkčních funkcí. A zatřetí nelze považovat přirozený monopol za něco trvalého, neměnného. Tak jak se společnost mění, mění se i „Millovy okolnosti“.

\section{Literatura}

BAUMOL, W. J. 1982. Contestable Market: An Uprising in the Theory of Industry Structure. The American Economic Review. 1982, vol. 72, no. 1, s. 1-15.

BAUMOL, W. J. 1977. On the Proper Cost Tests for Natural Monopoly in a Multiproduct Industry. The American Economic Review. 1977, vol. 67, no. 5, s. 809-833.

BONBRIGHT, J. C. 1961. Principles of Public Utility Rates. New York : Columbia University Press, 1961. 433 s. Dostupný z: www.terry.uga.edu/bonbright/pdfs/principles_of_public_utility_rates.pdf>. ISBN 231-02441-X.

COASE, R. H. 1937. The Nature of the Firm. Economica. 1937, vol. 14, no. 16, s. 386-405.

COMMONS, J. R. 1892. Protection and Natural Monopolies. The Quarterly Journal of Economics. 1892, vol. 6 , no. 4 , s. $479-484$.

DEMSETZ, H. 1968. Why Regulate Utilities? Journal of Law and Economics. 1968, vol. 11, no. 1, S. 55-65.

DiLORENZO, T. J. 1996. The Myth of Natural Monopoly. The Review of Austrian Economics. 1996, vol. 9, is. 2, s. 43-58.

ELY, R. T. 1894. Natural Monopolies and the Workingman. The North American Review. 1894, vol. 158, is. March, s. 294-303. Dostupný z: cdl.library.cornell.edu/cgi-bin/moa/pageviewer? root=\%2 Fmoa\%2Fnora\%2Fnora0158\%2F\&tif=00300.TIF\&cite=http\%3A\%2F\%2Fcdl.library.cornell.edu\%2Fc gi-bin\%2Fmoa\%2Fmoa-cgi\%3Fnotisid\%3DABQ7578-0158-36\&coll=moa\&frames=1\&view=50.

MALTHUS, T. R. 1815. The Nature of the Rent. 1815. Dostupný z: www.faculty.rsu.edu/ felwell/ Theorists/ Malthus/rent.htm. 
MARSHALL, A. 1920. Principles of Economics. 8.vyd. London: Macmillan, 1920. Dostupný z: www.econlib.org/library/Marshall/marP.html.

MILL, J. S. 1909. The Principles of Political Economy with some of their Applications to Social Philosophy. 7. vyd. London : Longmans, Green and Co., 1909. Dostupné z: www.econlib.org/library/ Mill/mIP.html.

MOSCA, M. 2007. On the Origins of the Concept of Natural Monopoly. [Working paper series No. 92/45]. Lecce (Italy): Universitŕ del Salento Dipartimento di Scienze Economiche e Matematico-Statistiche, 2007.

PANZAR, J. C., WILLIG, R. D. 1977. Economies of Scale in Multi-Output Production. The Quarterly Journal of Economics. 1977, vol. 91, no. 3, s. 481-493.

PANZAR, J. C.; WILLIG, R. D. 1981. Economies of Scope. The American Economic Review. 1981, vol. 71 , no. 2 , s. $268-272$.

PANZAR, J. C.; WILLIG, R. D. 1977. Free Entry and Sustainability of Natural Monopoly. The Bell Journal of Economics. 1977, vol. 8, no. 1, s. 1-22.

SENIOR, N. W. 1854. Political Economy. 3.vyd. London : Richard Griffin and Co., 1854. Dostupné z: www.econlib.org/library/Senior/snP.html.

SHARKEY, W. W. 1989. The Theory of Natural Monopoly. Cambridge : Cambridge University Press, 1989. 240 s. ISBN 0-521-27194-0.

SMITH, A. 1776. Pojednání o podstatě a původu bohatství národů. Praha : Liberální institut, 2001. 986 s. ISBN 80-86389-15-4.

WALRAS, L. 1875. L'état et les chemins de fer. 1875. Dostupný z: socserv2.socsci.mcmaster.ca/ $\sim$ econ/ugcm/3ll3/walras/walras.htm.

\title{
HISTORY OF NATURAL MONOPOLY CONCEPT
}

Martin Hon, Faculty of Economics, VSB-TU Ostrava, Sokolská 33, CZ - 70121

Ostrava (martin.hon@vsb.cz)

\begin{abstract}
The paper presents the evolution of the natural monopoly term in the economic literature. Using the citations of the authors the article shows various approaches to the natural monopoly concept from the very beginning till nowadays. The definition of natural monopoly has been changing over time and even today there is not the only one view used widespread.
\end{abstract}

\section{Keywords}

natural monopoly, economic history, political economy, cost function subadditivity, contestable market, monopoly power, economies of scale

\section{JEL classification}

B1, B2, B3 